\title{
2021 Handbook of Florida Water Regulation: State Regulatory Powers ${ }^{1}$
}

\author{
Michael T. Olexa, Tatiana Borisova, and Jana Caracciolo²
}

\section{Preface}

This handbook is designed to provide an accurate, current, and authoritative summary of the principal federal and state (Florida) laws that directly or indirectly relate to agriculture. This handbook provides a basic overview of the many rights and responsibilities that farmers and farmland owners have under both federal and state laws as well as the appropriate contact information to obtain more detailed information. However, the reader should be aware that because the laws, administrative rulings, and court decisions on which this handbook is based are subject to constant revision, portions of this publication could become outdated at any time. Several details of cited laws are also left out due to space limitations. This handbook is provided as an educational text for those interested in water use and water resource issues in Florida.

This handbook is distributed with the understanding that the authors are not engaged in rendering legal or other professional advice, and the information contained herein should not be regarded as a substitute for professional advice. This handbook is not all inclusive in providing information to achieve compliance with the federal and state laws and regulations governing water protection. For these reasons, the use of these materials by any person constitutes an agreement to hold harmless the authors, the UF/IFAS Center for Agricultural and Natural Resource Law, and UF/IFAS Extension for any liability claims, damages, or expenses that may be incurred by any person as a result of reference to or reliance on the information contained in this handbook. Note: UF/IFAS is the acronym for University of Florida, Institute of Food and Agricultural Sciences.

\section{State Law Overview}

State law typically supplements and often duplicates federal law. In many instances, however, state law standards are stricter than federal standards. Consequently, compliance with state law often assures compliance with federal laws as well. In a nutshell, state law takes two forms: statutes and administrative rules.

\section{What are statutes?}

Statutes are written laws passed by the state legislature. Statutes set out the basic goals of the legislature and the procedures the legislature requires state agencies to follow to accomplish these goals. Although statutes often provide fairly specific directions or prohibitions, many of the details of regulating an area of business or an aspect of the environment are too technical and minute for the legislature to address.

\section{What are administrative rules?}

The state legislature will generally rely on administrative agencies to carry out the specific goals of the legislature. To do so, the legislature empowers administrative agencies to

1. This document is FE581, one of a series of the Food and Resource Economics Department, UF/IFAS Extension. Original publication date October 1998. Revised June 2017 and April 2021. Visit the EDIS website at https://edis.ifas.ufl.edu for the currently supported version of this publication.

2. Michael T. Olexa, professor, Food and Resource Economics Department, and director, UF/IFAS Center for Agricultural and Natural Resource Law, and member of the Florida Bar; Tatiana Borisova, associate professor, Food and Resource Economics Department; and Jana Caracciolo, student, Levin College of Law; UF/IFAS Extension, Gainesville, FL 32611.

The Institute of Food and Agricultural Sciences (IFAS) is an Equal Opportunity Institution authorized to provide research, educational information and other services

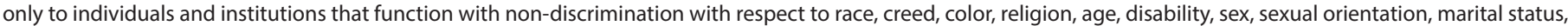

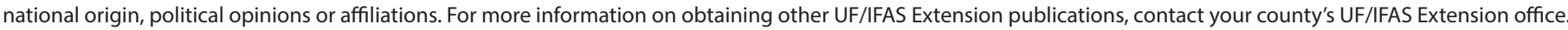
U.S. Department of Agriculture, UF/IFAS Extension Service, University of Florida, IFAS, Florida A \& M University Cooperative Extension Program, and Boards of County Commissioners Cooperating. Nick T. Place, dean for UF/IFAS Extension. 
adopt rules (which have the force of law) within the narrow bounds of their directive from the legislature.

For example, if the legislature decides that there is a state interest in regulating the use of certain pesticides, it may pass a statute that broadly outlines pesticide uses or prohibitions, then leave it to an agency (in this instance, the Florida Department of Agriculture and Consumer Services) to make rules about when, by whom, and in what quantities the pesticide must be applied. In most instances, agencies also have the power to enforce their rules through both criminal and civil penalties as well as through permitting/ licensing regulations.

\section{State Regulatory Powers}

\section{How are state and government actions restricted?}

To ensure that state agencies deal fairly with those who are subject to their regulation, Florida has passed the following laws:

\section{Florida Administrative Procedure Act (Chapter 120,} Florida Statutes) provides the chief mechanism for private input into agency actions and rulemaking. This Act establishes many procedural rights such as the right to be heard by the agency, the right to receive notice of agency actions, and a guaranteed opportunity for those who are most affected to use those rights.

\section{Florida Public Records Law (Chapter 119, Florida} Statutes) provides that all agency records, with a few statutory exceptions, are available for public inspection and copying. Exceptions arise where the confidentiality of the information is necessary for efficient government administration or where disclosure would adversely affect law enforcement.

\section{Florida Sunshine Law (Chapter 286, Florida Statutes)} declares that all meetings of any governmental body where any official action is taken must be open to the public and the minutes must be recorded. This statute is not an unconditional guarantee of access to government, but goes a long way toward keeping administrative bodies accountable to the public.

\section{What is the structure of the Florida agencies?}

The majority of state agencies have similar structures. In Florida, most maintain their headquarters in Tallahassee and have regional offices throughout the state. Within each agency, there may be various divisions, each with its own set of duties (e.g., permitting, enforcement, or public information). Many agencies are headed by a secretary who reports to the governor. Other agencies are headed by a cabinet officer or appointed commissioner who reports to the legislature to keep abreast of policy changes and to maintain accurate up-to-date rules.

The structure of city and county governments varies from government to government, but each has its own divisions that range from small rural areas to large urban areas. Each county and city is headed by an elected commission. Some rely on professional managers to run the day-to-day aspects of government while others rely on elected officials. It is important to note that these local agency entities do not have the same authority as a state agency and only wield authority within each agency's defined boundaries.

\section{What are the differences between civil, criminal, and administrative punishment?}

Violations of laws and policies can result in civil, criminal and/or administrative penalties. Generally speaking, civil law deals with disputes brought by private parties, both individuals and organizations, against other individuals, organizations, or the government.

Civil penalties are designed to "cure" the harm to an individual or organization or to settle a dispute between such parties, and are resolved in a variety of judgments. Civil penalties are generally characterized by monetary damages or injunctions (court order to stop some action), not imprisonment (a purely criminal penalty).

In contrast, criminal penalties are used as punishment for violation of the law, and can only be enforced by a government entity. Criminal violations are divided into misdemeanors and felonies. Misdemeanors are crimes that are punishable by imprisonment of one year or less. Felonies are crimes that are punishable by imprisonment of more than one year. Misdemeanors and felonies are further classified by degrees according to the level of severity, with first degree crimes being the most serious.

Administrative law regulates administrative agencies and issues. The appropriate state or federal administrative procedure law, as well as the relevant state and/or federal statutes, govern administrative agencies. Administrative agencies have the authority to make rules that have the force of law and to adjudicate violations just as traditional courts do. Administrative agencies have the ability to impose both financial and criminal penalties on parties under agency 
authority to the extent those penalties are established in the relevant statutes or rules.

\section{Acknowledgments}

The authors are indebted to the personnel of both state and federal agencies who provided their time and advice in the preparation of this handbook. We acknowledge Carol Fountain and Susan Gildersleeve at the University of Florida for their assistance in editing this handbook. We also acknowledge funding received for updating this publication from the James S. and Dorothy F. Wershow UF/ IFAS Center for Agricultural and Natural Resource Law Endowment. 